\title{
MODEL DINAMIKA PERUBAHAN PENGGUNAAN LAHAN DAN ALIRAN PERMUKAAN DI DAS CILIWUNG HULU
}

\author{
Erwin Hermawan 1), Santun RP Sitorus'), Marimin ${ }^{3)}$, Surya Darma Tarigan²) \\ 1) Mahasiswa S3, Pengelolaan Sumberdaya alam dan Lingkungan, Pascasarjana IPB - Bogor \\ 1) Jurusan Teknik Infomatika, Fakultas Teknik, Universitas Ibn Khaldun - Bogor \\ 2) Departemen Ilmu Tanah dan Sumberdaya Lahan, Fakultas Pertanian, IPB - Bogor \\ 3) Departemen Teknologi Industri Pertanian, Fakultas Teknologi Pertanian, IPB - Bogor
}

\begin{abstract}
ABSTRAK
Pengembangan model dinamika perubahan penggunaan lahan dan aliran permukaan di DAS Ciliwung Hulu ini adalah bertujuan untuk : (1). Mengetahui perilaku peningkatan aliran permukaan sebagai dampak dari peningkatan penduduk dan peningkatan luasan lahan terbangun dan (2). Mencari skenario - skenario kebijakan untuk menurunkan laju aliran permukaan. Hasil pemodelan menunjukkan bahwa Peningkatan akan laju aliran permukaan dipicu oleh peningkatan jumlah penduduk yang berdampak langsung pada peningkatan kebutuhan lahan untuk area terbangun. Hal ini berdampak signifikan terhadap peningkatan laju aliran permukaan setiap tahunnya. Upaya pengendalian akan peningkatan aliran permukaan dapat dilakukan dengan menerapkan beberapa skenario kebijakan. Berdasarkan hasil simulasi, skenario III memberikan hasil yang terbaik dalam upaya pengendalian aliran permukaan di DAS Ciliwung Hulu. Skenario III didasarkan pada kebijakan dengan intervensi penekanan angka kelahiran dan emigrasi dan juga pengendalian terhadap tata ruang, memberikan hasil yang cukup signifikan untuk menurunkan laju aliran permukaan dibandingkan dengan kondisi eksisting tanpa dilakukan intervensi kebijakan.
\end{abstract}

Kata kunci : Model dinamika Perubahan Penggunaan Lahan, Aliran Permukaan, Skenario Kebijakan

\section{PENDAHULUAN}

\section{Latar Belakang}

Peningkatan jumlah penduduk di sekitar daerah puncak bogor dari tahun ke tahun menyebabkan tekanan pembangunan yang tinggi pada DAS Ciliwung Hulu, sehingga DAS ini tergolong salah satu DAS yang mengalami degradasi. Kondisi ini dicirikan oleh pengelolaan lahan yang tidak sesuai dengan kemampuannya dan tidak disertai dengan usaha konservasi tanah dan air, serta perubahan pola penggunaan lahan bervegetasi (Yustika et al, 2012). Ruspendi, 2014 menyebutkan bahwa Perubahan penggunaan lahan di DAS Ciliwung Hulu telah terjadi dari penutupan vegetasi yang baik menjadi kawasan terbangun dengan menurunnya tutupan lahan hijau yang cukup masif yaitu dengan laju $1.95 \%$ per tahun dan peningkatan penggunaan lahan untuk permukiman dengan laju sebesar $12.34 \%$ per tahun.

Konversi lahan pada umumnya terjadi pada penggunaan lahan hutan menjadi daerah perkebunan dan pertanian, daerah perkebunan menjadi lahan pertanian dan permukiman, daerah pertanian menjadi permukiman dan industri. Tidak jarang terdapat daerah hutan dan perkebunan yang berubah menjadi lahan kosong, terlantar dan gundul yang kemudian menjadi lahan kritis. Hadi (2012) mengemukakan bahwa, berdasarkan hasil analisa penggunaan lahan, luas permukiman di DAS Ciliwung hulu meningkat secara substansial dari 2001 sampai 2010 (meningkat $67.88 \%$ ). Konversi lahan dari area bervegtasi menjadi lahan terbangun akan meningkatkan koefisien run off yang pada akhirnya akan terjadi peningkatan laju aliran permukaan seiring dengan semakin meningkatnya luasan lahan terbangun.

\section{Tujuan}

Tujuan dari penulisan ini adalah membuat suatu model dalam upaya untuk pengendalian Aliran Permukaan di DAS Ciliwung Hulu. 


\section{TINJAUAN PUSTAKA}

\section{Sistem, Model dan Pemodelan}

Sistem adalah bagian dari alam semesta yang dapat dibedakan dengan jelas, dari lingkungan luarnya, baik oleh batas fisik mapun oleh batas-bataskonseptual. Turunan pertama sebuah sistem adalah sub sistem. Unsur yang membentuk sistem atau subsistem, dimana unsur tersebut saling berinteraksi disebut komponen. Hirarki ini Tidak mutlak karena setiap komponen mungkin masih bisa diuraikan lebih terinci menjadi subsistem yang lebih kompleks (Hillel, 1977). Lebih lanjut (Hartrisari, 2007) mengemukakan bahwa sistem adalah gugus atau kumpulan dari komponen yang saling terkait dan terorganisasi dalam rangka mencapai suatu tujuan atau gugus tujuan tertentu.

Model adalah abstraksi atau penyederhaaan dari dunia nyata, yang mampu menggambarkan struktur dan interaksi elemen serta perilaku keseluruhannya sesuai dengan sudut pandang dan tujuan yang diinginkan (Purnomo, 2005). Pengertian singkat dan sederhana datang dari pakar modeling Alexey Voinov (2008) yang menyatakan bahwa $A$ model is a simplification of reality. Odum (1971) menggolongkan model menjadi tiga bentuk, yakni model miniatur, model analog, dan model simbolik atau matematik. Model ilmiah harus dmyatakan secara ringkas, tepat, obyektif, universal dan luwes. Model-model matematik yang sudah dikenal adalah model empiris, model deterministik model stokastik, model analisis, model numeris, model kontinyu, dan model dinamik atau modifikasinya (Hillel, 1977).

Pemodelan (modelling) adalah kegiatan membuat model untuk tujuan tertentu. Model adalah abstraksi dari sebuah sistem. Sistem adalah sesuatu yang terdapat di dunia nyata (real world). Sehingga pemodelan adalah kegiatan membawa sebuah dunia nyata kedalam dunia tak nyata atau maya tanpa kehilangan sifat-sofat utamanya (Purnomo, 2005).

Menurut Jorgensen, (1988) penggunaan model dalam analisis ekologi sangat menguntungkan dan merupakan alat analisis ilmiah karena:

a. Model sangat berguna sebagai instrumen dalam survey untuk sistem yang kompleks;

b. Model dapat digunakan untuk menggambarkan sifat-sifat sistem;

c. Keluaran dari model dapat mengatasi kelemahan pengetahuan sehingga dapat digunakan untuk menentukan proritas dalam kegiatan penelitian;

d. Model sangat berguna untuk menguji hipotesa ilmiah, karena model dapat mensimulasikan reaksi ekosistem, yang dibandingkan dengan data hasil pengamatan.

\section{Tahapan Pemodelan Sistem}

Tahapan pembentukan dan penggunaan sebuah model sistem. meliputi (Purnomo, 2005; Grant et. al., 1997) :

1. Identifikasi Isu, Tujuan dan Batasan. Bertujuan untuk mengidentifikasi isu sehingga permasalahan dapat dilihat dengan tepat. Setelah isu ditentukan, berikutnya adalah menentukan tujuan pemodelan tersebut. Isu yang diangkat dan tujuan pemodelan dinyatakan secara eksplisit. Setelah isu dan tujuan ditetapkan, ditentukan batasan pemodelan yang dibangun untuk kejelasan apa yang termasuk dan tidak termasuk dalam pemodelan. Batasan dapat berupa batas daerah atau ruang, batas waktu, atau dapat juga batas isu.

2. Perumusan Model Konseptual. Tahapan ini bertujuan membangunpemahaman terhadap sistem yang diamati ke dalam sebuah konsep untuk mendapatkan gambaran secara menyeluruh tentang model yang akan dibuat. Tahapan ini dimulai dengan mengidentifikasi semua komponen yangterlibat atau dimasukkan dalam pemodelan. Jika komponen-komponentersebut sangat banyak maka dapat dikelompokkan dalam beberapa kategori. Komponen-komponen tersebut kemudian dicari hubungannya satu sama lain dengan menggunakan diagram kotak dan panah. Dalam konseptualisasi model ini, perlu diperhatikan bahwa komponenkomponen yang membentuk sistem harus bersifat dinamis, sensitif terhadap perubahan serta keterkaitannya dalam sistem membentuk hubungan sebab-akibat. Identifikasi keterkaitan komponen tersebut didasarkan padas keadaannyata agar hasil yang digambarkan model mendekati keadaan sebenarnya.

3. Spesifikasi Model Kuantitatif. Bertujuan untuk membentuk model kuantitatif dari konsep model yang telah ditetapkan dengan memberikan nilai kuantitatifterhadap masingmasing variabel dan menterjemahkan hubungan antarvariabel dan komponen penyusun model sistem tersebut ke dalam persamaan matematika. Persamaan tersebut dapat diperoleh dari hasil regresi terhadap data yang ada, hasil rujukan atau berdasarkan rekaan yang dapat dipertanggung-jawabkan. 
Secara rinci tahapan dalam spesifikasi model kuantitatif terdiri dari :

- Memilih dan menentukan struktur kuantitas model

- Menentukan satuan waktu dalam simulasi

- Identifikasi bentuk-bentuk fungsional dari persamaan model

4. Evaluasi Model. Bertujuan untuk mengetahui keterhandalan model untuk mendeskripsikan keadaan sebenarnya. Proses pengujian dilakukan dengan mengamati kelogisan model dan membandingkan dengan dunia nyata atau model andal yang serupa jika ada. Setelah setiap bagian dari model diamati apakah relasi-relasi yang ada logis atau tidak, maka selanjutnya diamati logis tidaknya keterkaitan antar bagian sebagai model yang utuh. Logis dalam hal ini berarti bahwa ada penalaran yang memadai dari relasi-relasi tersebut dan bukan berarti bahwa semua persamaan sesuai dengan apa yang dipercayai orang atau dengan kata lain sesuai dengan paradigma yang ada. Tahapan kedua dari evaluasi model ini adalah mengamati apakahperilaku model sesuai dengan harapan atau perkiraan yang digambarkan pada tahapan konseptualisasi model. Model dijalankan atau dieksekusi pada sebuah komputer, dan diamati hasilnya apakah beberapa komponen yang diamati atau menjadi fokus perhatian sesuai dengan pola perilaku yang diharapkan, jika belum sesuai maka harus dilakukan perbaikan model.

\section{Model Hidrologi}

Rauf (1994) menjelaskan bahwa model hidrologi adalah sebuah gambaran sederhana dari suatu sistem hidrologi yang aktual. Dooge dalam Harto (1993)menyatakan pengertian sistem sebagai suatu struktur, alat, skema atau prosedur,baik riil maupun abstrak, yang dikaitkan dalam satu refrensi waktu tertentu sebuah masukan atau sebab, tenaga atau informasi dengan keluaran pengaruh atau tanggapan secara menyeluruh.

Tujuan penggunaan model dalam hidrologi diantaranya : (1) peramalan (forecasting), termasuk didalamnya untuk sistem peringatan dan manajemen. Peramalan memberikan maksud bahwa baik besaran ataupun waktu kejadian yang dianalisis berdasar cara probabilistik, (2) perkiraan (prediction), memberikanpengertian bahwa besaran kejadian dan waktu hipotetik (hypothetical future time), (3) sebagai alat deteksi dalam masalah pengendalian. Dengan sistem yang telahpasti dan keluaran yang diketahui maka masukan dapat dikontrol dan diatur, (4)sebagai alat pengenal (identification tool) dalam masalah perencanaan (planning),(5) eksplorasi data/informasi, (6) perkiraan lingkungan akibat perilaku manusia yang berubah/meningkat dan (7) penelitian dasar dalam proses hidrologi (Harto, 1993).

Pada siklus hidrologi terdapat beberapa proses yang saling terkait mencerminkan pergerakan air, meliputi proses presipitasi, evaporasi, transpirasi,intersepsi, infiltrasi, perkolasi, aliran limpasan, aliran air bawah tanah. Selanjutnya proses Evapotranspirasi, intersepsi, infiltrasi, perkolasi, aliran disebut sebagaikomponen ketersediaan air. Pergerakan air pada suatu DAS merupakan manifestasi dari siklus hidrologi untuk mencapai keseimbangan ketersediaan air di bumi. Konsep keseimbangan air adalah water balance atau persamaan air(viessman et.al, 1977, Arsyad, 1989), yaitu:

$$
\mathrm{AP}=\mathrm{P}-\mathrm{IN}-\mathrm{ET}-\mathrm{PE}-\Delta \mathrm{SA}
$$

Aliran permukaan (AP); curah hujan (P); intersepsi (IN); evapotranspirasi (ET); Perkolasi (PE); dan perubahan simpanan air $(\Delta \mathrm{SA})$. Proses pergerakan air tersebut dapat ditiru dan diwujudkan dalam bentuk model. Pemodelan hidrologi untuk perhitungan limpasan telah banyakdikembangkan sejak tahun 1960-an, mulai dari yang sangat sederhana hinggapemodelan yang rumit. Pemodelan yang rumit ini umumnya tersusun dari sub-model yang masing-masing menerangkan proses-proses hidrologi (Hadi, 2003).

\section{HASIL DAN PEMBAHASAN}

Pengembangan model dinamika perubahan penggunaan lahan dan aliran permukaan di DAS Ciliwung Hulu dibangun dengan menggunakan metode pendekatan sistem. Tahapan yang dilakukan dalam pengembangan model tersebut meliputi tahapan : 1). Identifikasi isu, tujuan dan batasan; 2). Konseptualisasi model; 3). Spesifikasi model; 4). Evaluasi model; serta 5). Penggunaan model. Penjelasan dari tiap tahapan dijelaskan sebagai berikut :

\section{Identifikasi Isu, Tujuan dan Batasan}

Peningkatan jumlah penduduk di sekitar daerah puncak bogor dari tahun ke tahun menyebabkan tekanan pembangunan yang tinggi pada DAS Ciliwung Hulu, sehingga DAS ini tergolong salah satu DAS yang mengalami degradasi. Kondisi ini dicirikan oleh pengelolaan lahan yang tidak sesuai dengan kemampuannya dan tidak disertai dengan usaha konservasi tanah 
dan air, serta perubahan pola penggunaan lahan bervegetasi (Yustika et al, 2012). Ruspendi, 2014 menyebutkan bahwa Perubahan penggunaan lahan di DAS Ciliwung Hulu telah terjadi dari penutupan vegetasi yang baik menjadi kawasan terbangun dengan menurunnya tutupan lahan hijau yang cukup masif yaitu dengan laju $1.95 \%$ per tahun dan peningkatan penggunaan lahan untuk permukiman dengan laju sebesar $12.34 \%$ per tahun.

Konversi lahan pada umumnya terjadi pada penggunaan lahan hutan menjadi daerah perkebunan dan pertanian, daerah perkebunan menjadi lahan pertanian dan permukiman, daerah pertanian menjadi permukiman dan industri. Tidak jarang terdapat daerah hutan dan perkebunan yang berubah menjadi lahan kosong, terlantar dan gundul yang kemudian menjadi lahan kritis. Hadi (2012) mengemukakan bahwa, berdasarkan hasil analisa penggunaan lahan, luas permukiman di DAS Ciliwung hulu meningkat secara substansial dari 2001 sampai 2010 (meningkat $67.88 \%$ ). Konversi lahan dari area bervegtasi menjadi lahan terbangun akan meningkatkan koefisien run off yang pada akhirnya akan terjadi peningkatan laju aliran permukaan seiring dengan semakin meningkatnya luasan lahan terbangun.
Mencari skenario - skenario untuk menurunkan laju aliran permukaan.

Sedangkan batasan yang digunakan dalam pengembangan model ini adalah :

1. Pemodelan dilakukan di Sub DAS Ciliwung Hulu

2. Curah Hujan di asumsikan konstan untuk setiap tahunnya.

3. Simulasi aliran permukaan dilakukan per tahun.

Pemodelan dilakukan di Sub DAS Ciliwung Hulu

Curah Hujan di asumsikan konstan untuk setiap tahun

Simulasi aliran permukaan dilakukan per tahun.

\section{Konseptualisasi Model}

Tahap ini mencoba untuk menjelaskan alur pikiran atas model tersebut, sehingga dapat dimengerti oleh orang lain. Konseptual model dikembangkan dari hasil identifikasi isu, tujuan dan batasan kemudian dikembangkan dalam sebuah model mental. Guna melihat interkasi antar komponen dalam suatu sistem berdasarkan

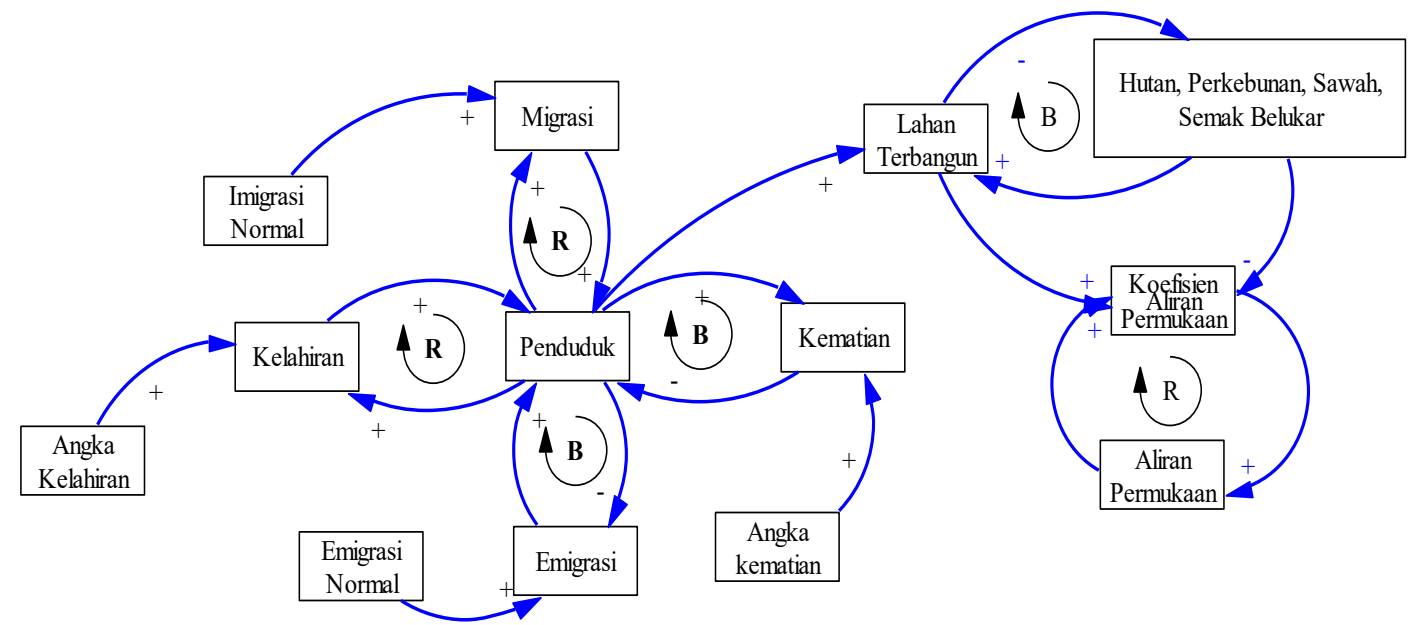

Dari isu di atas, maka tujuan yang ingin dicapai dalam pembuatan model dinamika perubahan penggunaan lahan dan aliran permukaan di DAS Ciliwung Hulu ini adalah :

1. Mengetahui perilaku peningkatan aliran permukaan sebagai dampak dari model mental yang dibangun, maka dibuatkan dalam suatu bentuk hubungan grafik sebab akibat (causal loop).

Gambar 1, menunjukkan hubungan interaksi sebab akibat antar komponen dalam pengembangan model dinamika perubahan

\section{Gambar 1. Model konseptual sistem yang dikembangkan}

peningkatan penduduk dan peningkatan luasan lahan terbangun

2. Mencari skenario - skenario untuk menurunkan laju aliran permukaan. penggunaan lahan dan aliran permukaan di DAS Ciliwung Hulu. Identifikasi awal dari permasalahan yang terjadi adalah dari isi peningkatan jumlah penduduk yang semakin meningkat di Kawasan puncak - Bogor. 
Pendekatan sistem dalam dinamika populasi adalah Kelahiran dan Emigrasi menjadi faktor inflow yang akan menambah jumlah penduduk, sedangkan kematian dan imigrasi akan menjadi faktor outflow yang mengurangi jumlah penduduk. Peningkatan jumlah penduduk pada suatu area kan menyebakan permintaan lahan akan lahan terbangun akan semakin meningkat. Hal inilah yang menjadi pemicu pemenuhan kebutuhan lahan terbangun dengan melakukan konversi lahan dari area lahan hutan , perkebunan, sawah dan semak belukar menjadi area terbangun.

Peningkatan lahan area terbangun secara langsung akan menyebakan berkurangnya area lahan bervegetasi yang pada akhirnya berdampak pada peningkatan koefisien aliran permukaan. Secara signifikan, peningkatan koefisien aliran permukaan sebagai dampak dari konversi lahan bervegetasi menjadi area tebangun akan meningkatkan laju aliran permukaan.

\section{Spesifikasi Model}

Pada tahap ini kuantifikasi dan perumusan hubungan antar komponen dilakukan sehingga model bisa dijalankan pada komputer. Model dinamika perubahan penggunaan lahan dan aliran permukaan di DAS Ciliwung Hulu di bagi dalam 3 Sub Model, yakni (1) Sub Model Penduduk, (2) Sub Model Landuse dan (3) Sub Model Aliran Permukaan. Gambar 2 menyajikan interkasi antar 3 sub model yang dikembangkan.

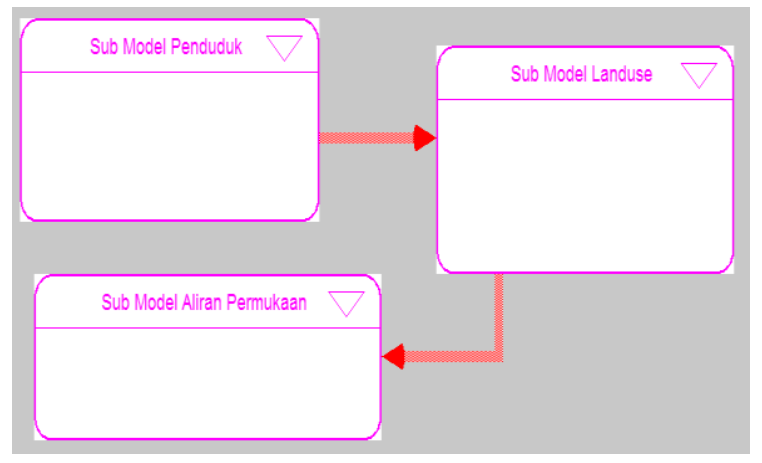

Gambar 2. Spesifikasi Model yang dikembangkan

Sub Model Penduduk akan melakukan simulasi perilaku dinamika populasi yang berdampak langsung pada dinamika perilaku perubahan penggunaan lahan dalam Sub Model Penggunaan Lahan. Pada akhirnya, dinamika perubahan penggunaan lahan akan berdampak signifikan pada peningkatan perilaku laju aliran permukaan di DAS Ciliwung Hulu.

\section{Spesifikasi sub model dinamika penduduk}

Sub model ini menggambarkan populasi penduduk untuk mengetahui jumlah pertambahan penduduk dan juga jumlah penduduk yang berpengaruh terhadap konversi lahan. Pertambahan penduduk dipengaruhi oleh kelahiran dan perpindahan masuk penduduk ke daerah tersebut (emigrasi), sedangkan pengurangan penduduk dipengaruhi oleh kematian dan perpindahan keluar penduduk dari daerah tersebut.

Jumlah penduduk pada saat awal (initial) adalah sebanyak 17600 orang. Berdasarkan hasil studi literature dari beberapa pustaka, didapatkan angka kelahiran sebesar $7 \%$, angka kematian sebesar $3 \%$ ( BPS Kabupaten Bogor, 2014 ; Ruspendi, 2014 ; Yustika , 2012). Sedangkan untuk Tingkat Emigrasi dan Imigrasi masing masing diasumsikan $1 \%$ dan $2 \%$. Gambar 3 . Menggambarkan Stock Flow Diagram Sub Model Dinamika Penduduk

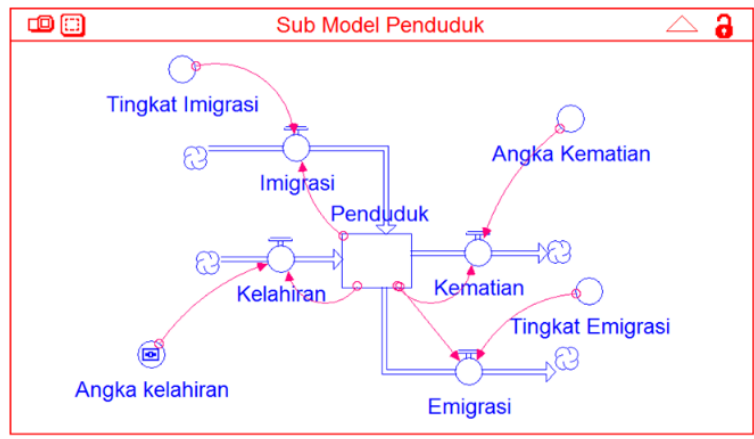

Gambar 3. Stock Flow Diagram Sub Model Dinamika Penduduk

\section{Spesifikasi sub model dinamika Penggunaan lahan.}

Dinamika perubahan penggunaan lahan sangat dipengaruhi oleh dinamika populasi pada suatu area. Semakin meningkatnya jumlah penduduk akan berdampak pada peningkatan kebutuhah akan lahan terbangun. Sebagai konsekuensi logis dari hal tersebut, akan semakin meningkatnya konversi lahan dari lahan hutan, perkebunan, sawah dan lahan terbuka menjadi area terbangun.

Secara rinci Stock Flow Diagram Sub Model Dinamika penggunaan lahan disajikan pada Gambar 4.

Beberapa asumsi digunakan dalam pemodelan, untuk mendapatkan laju konversi dari hutan, perkebunan, sawah dan semak belukar menjadi area terbangun. Asumsi dan hubungan matematis konversi penggunaan lahan di DAS Ciliwung Hulu disajikan dalam Equation yang terdapat pada Lampiran 2. 


\section{Evaluasi Model}

Evaluasi model dilakukan untuk menguji keterandalan model dalam menjelaskan fenomena yang terjadi di sistem nyata. Tujuannya untuk mengamati sejauh mana model yang dirancang mampu memprediksi dengan

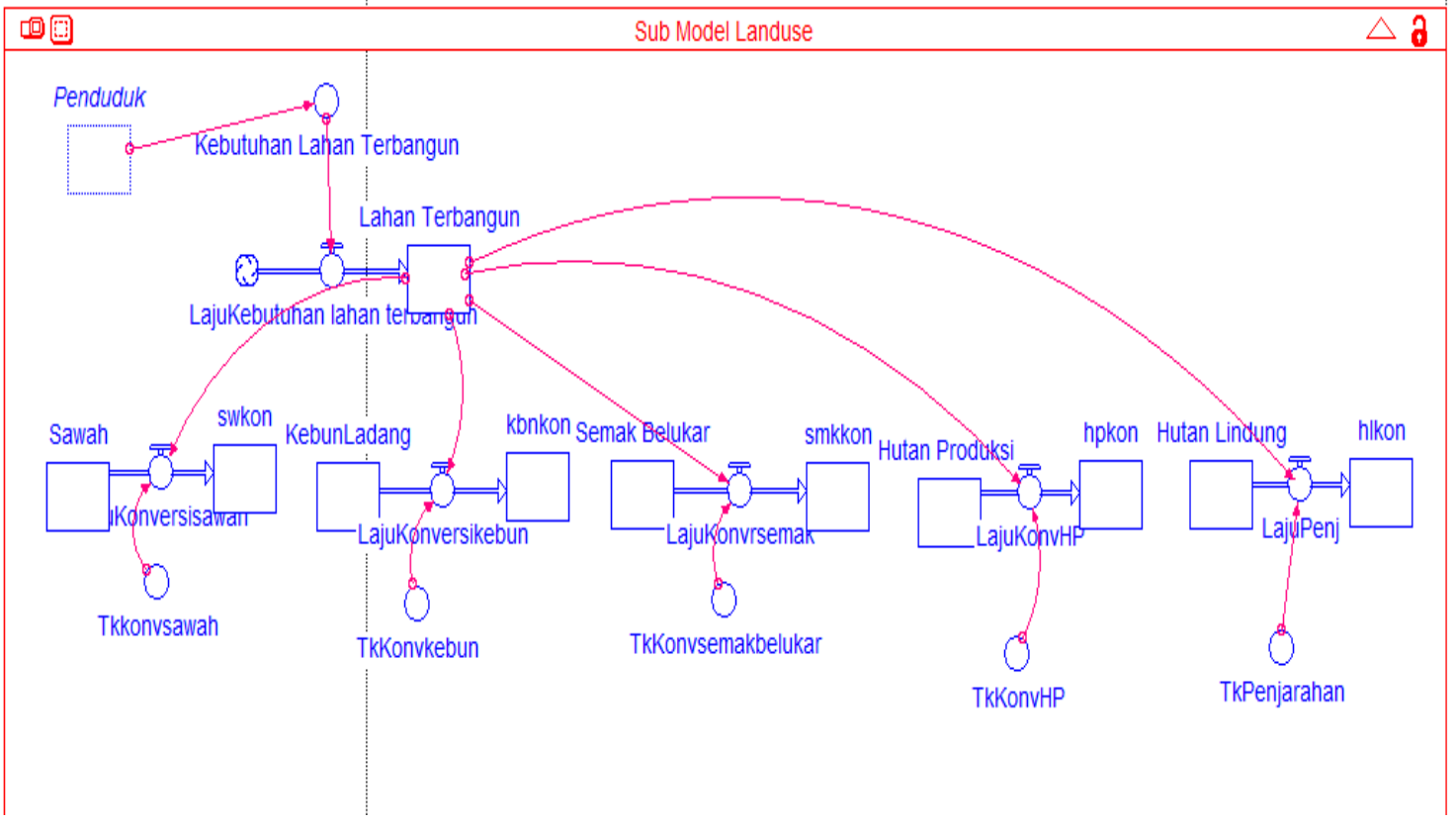

Gambar 4. Stock Flow Diagram Sub Model Dinamika Perubahan Lahan

\section{Spesifikasi sub model Aliran Permukaan}

Sub Model Aliran permukaan merupakan sub model yang terkait dengan dua sub model sebelumnya yakni model dinamika populasi dan model dinamika penggunaan lahan. Pendekatan Rasional digunakan dalam melakukan estimasi aliran permukaan di DAS Ciliwung Hulu yang dipengaruhi oleh intensitas hujan, luasan penggunaan lahan dan koefisien run off. Dalam pemodelan ini, intensitas hujan diasumsikan tetap, sedangakan luasan penggunaan lahan bersifat dinamik. Stock flow diagram dari sub model aliran permukaan tersaji pada Gambar 5.

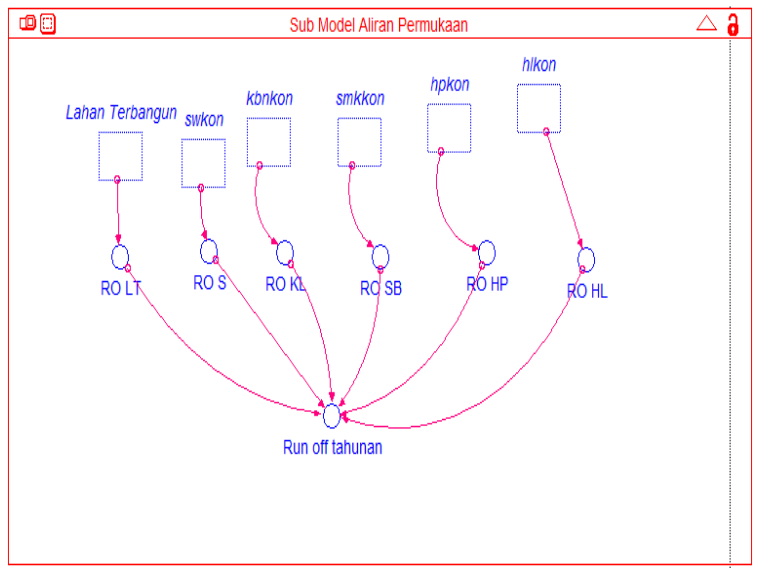

Gambar 5. Stock Flow Diagram Sub Model Aliran Permukaan baik apabila nilai masukan diubah (Sunaryo et al., 2006).

Dalam melakukan Evaluasi model, setiap bagian dari model diamati apakah relasi-relasi yang ada logis atau tidak, maka selanjutnya diamati logis tidaknya keterkaitan antar bagian sebagai model yang utuh. Logis dalam hal ini berarti bahwa ada penalaran yang memadai dari relasi-relasi tersebut dan bukan berarti bahwa semua persamaan sesuai dengan apa yang dipercayai orang atau dengan kata lain sesuai dengan paradigma yang ada (Purnomo, 2012).

Proses evaluasi Model dinamika perubahan penggunaan lahan dan aliran permukaan di DAS Ciliwung Hulu, belum dilakukan secara sistematis berdasarkan perpektif pengambil keputusan pada badan / instansi terkait pengelolaan DAS Ciliwung Hulu. Namun demikian, proses evaluasi model dilakukan dengan mengamati kelogisan dan keterkaitan antar variable yang digunakan dalam sistem secara utuh dan membandingkan hasil dari model yang didapatkan dengan beberapa hasil penelitian yang pernah dilakukan.

Hasil evaluasi kelogisan model dan perbandingan dengan pola yang diharapkan dari model, disajikan pada Tabel 1 . 
Tabel 1. Evaluasi Model

\begin{tabular}{lcc}
\hline \multicolumn{1}{c}{ Model } & Kelogisan & $\begin{array}{c}\text { Perbandingan } \\
\text { Perilaku Model } \\
\text { dengan Pola } \\
\text { yang } \\
\text { diharapkan }\end{array}$ \\
\hline $\begin{array}{l}\text { Model Secara } \\
\text { Keseluruhan }\end{array}$ & Ya & Sesuai \\
\hline $\begin{array}{l}\text { Sub Model } \\
\text { Dinamika } \\
\text { Penduduk }\end{array}$ & Ya & Sesuai \\
\hline $\begin{array}{l}\text { Sub Model } \\
\text { Dinamika } \\
\text { Landuse }\end{array}$ & Ya & Sesuai \\
\hline $\begin{array}{l}\text { Sub Model } \\
\text { Aliran } \\
\text { Permukaan }\end{array}$ & Ya & Sesuai \\
\hline
\end{tabular}

Ya

Sesuai

\section{Penggunaan Model}

Pada tahapan ini diterapkan beberapa proses skenario yang digunakan sebagai bahan dasar untuk membantu stakeholders dalam membuat kebijakan publik. Skenario kebijakan yang dibuat terkait dengan pengendalian peningkatan aliran permukaan di DAS Ciliwung Hulu sebagai dampak dari perubahan penggunaan lahan. Terdapat 3 skenario kebijakan yang dilakukan simulasi terhadap model yang sudah dikembangkan.

A. Skenario Kebijakan I : Sesuai dengan kondisi eksisting tanpa dilakukan intervensi terhadap sistem (pesimis).

Skenario Kebijakan I : Sesuai dengan kondisi eksisting tanpa melakukan intervensi (pesimis).

Skenario I merupakan skenario pesimistik, dimana tidak dilakukan intervensi terhadap sistem artinya kondisi tetap sesuai dengan kondisi eksisting. Hasil simulasi terhadap perilaku sistem yang menggambarkan perilaku dari dinamika populasi, dinamika perubahan penggunaan lahan dan dinamika aliran permukaan, berturut - turut disajikan pada Gambar 6, 7 dan 8.

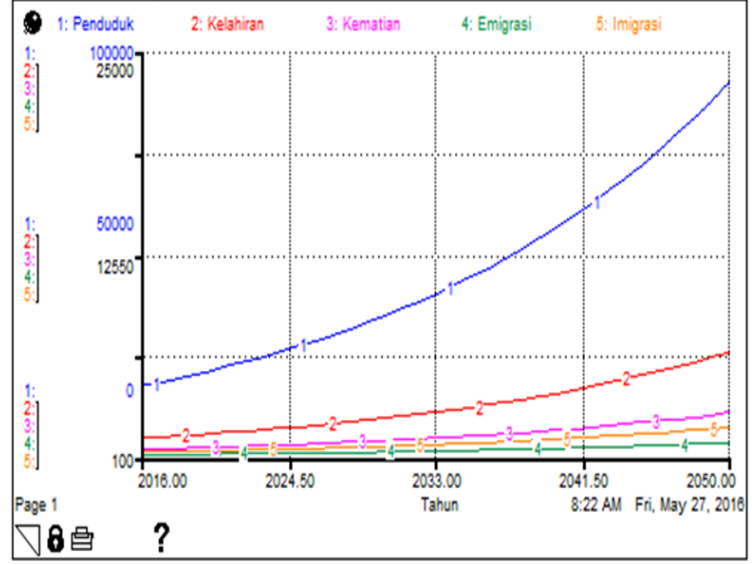

(a) Grafik Perilaku Dinamika populasi berdasarkan skenario 1

\begin{tabular}{|c|c|c|c|c|c|c|}
\hline \multicolumn{2}{|c|}{ O8:22AM 5/27/2018 } & \multicolumn{3}{|c|}{ Table 3 (Unititles Table) } & \multirow{2}{*}{ Imigrasi } & \multirow{2}{*}{ 箔 8} \\
\hline Tahun & Penduduk & Kelahiran & Kematian & Emigrasi & & \\
\hline 2016 & \begin{tabular}{l|l}
6 & $17,000.00$
\end{tabular} & $1,232.00$ & 528.00 & 178.00 & 352.00 & \\
\hline 2017 & $7 \quad 18,480.00$ & $1,293.60$ & 554.40 & 184.80 & 399.80 & \\
\hline 2018 & \begin{tabular}{l|l}
8 & $19,404.00$
\end{tabular} & $1,356.28$ & 582.12 & 194.04 & 388.08 & \\
\hline 2019 & 9 $20,374.20$ & $1,428.19$ & 611.23 & 203.74 & 407.48 & \\
\hline 2020 & $\begin{array}{ll}0 & 21,392.91\end{array}$ & $1,497,60$ & 641.79 & 213.98 & 427.88 & \\
\hline 2021 & $22,462.58$ & $1,572.38$ & 673.88 & 224.68 & 449.25 & \\
\hline 2022 & $23,585.88$ & $1,651.00$ & 707.57 & 235.88 & 471.71 & \\
\hline 2023 & $24,784.97$ & $1,733.65$ & 742.95 & 247.85 & 495.30 & \\
\hline 2024 & $28,003.22$ & $1,820.23$ & 780.10 & 280.03 & 520.08 & \\
\hline 2025 & $27,303.38$ & $1,911.24$ & 819.10 & 273.03 & 548.07 & \\
\hline 2028 & $28,688.55$ & $2,0008.80$ & 880.08 & 288.89 & 573.37 & \\
\hline 2027 & $30,101.97$ & $2,107,14$ & 903.08 & 301,02 & 002.04 & \\
\hline 2028 & $31,807,07$ & 2.212 .49 & 948.21 & 318.07 & 632.14 & \\
\hline & 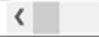 & & & & & \\
\hline
\end{tabular}

Grafik Perilaku Dinamika populasi berdasarkan skenario 1

(b) Proyeksi Dinamika Populasi berdasarkan skenario 1

Gambar 6. Hasil Simulasi Dinamika Populasi pada Skenario 1

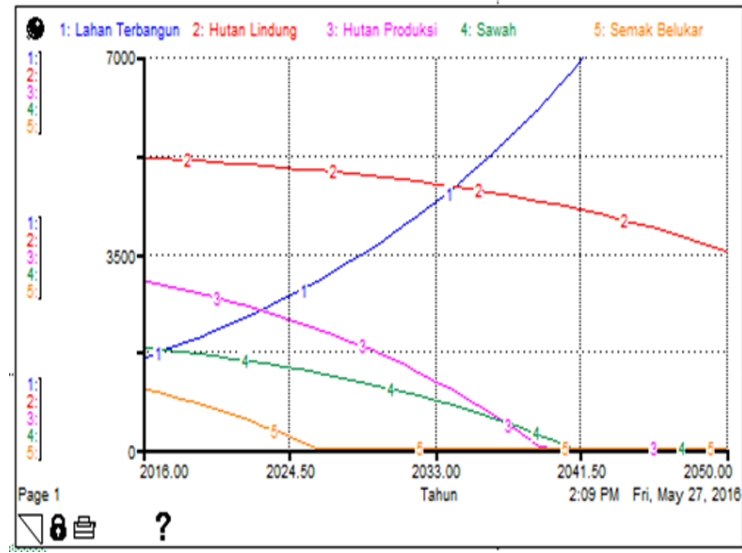

(a) Grafik Perilaku Dinamika Perubahan Penggunaan Lahan berdasarkan skenario 1

Grafik Perilaku Dinamika Perubahan Penggunaan Lahan berdasarkan skenario 1 


\begin{tabular}{|c|c|c|c|c|c|c|}
\hline \multicolumn{3}{|c|}{ 7:47 AM $5 / 27 / 2016$} & \multicolumn{3}{|c|}{ Table 1: p1 (SKENARIO 1) } & \multirow[t]{2}{*}{$?$} \\
\hline Tahun & Lahan Terbar & Sawah & KebunLadand & Semak Beluk & Hutan Produl & \\
\hline 2016 & $1,633.52$ & $1,782.02$ & $2,227.52$ & $1,039.51$ & $2,970.03$ & $5,197.55$ \\
\hline 2017 & $1,741.23$ & $1,749.35$ & $2,132.78$ & 961.10 & $2,907.96$ & $5,181.22$ \\
\hline 2018 & $1,854.33$ & $1,714.52$ & $2,031.79$ & 877.52 & $2,841.79$ & $5,163.81$ \\
\hline 2019 & \begin{tabular}{|l|l|}
$1,973.08$ \\
\end{tabular} & $1,677.44$ & $1,924.24$ & 788.52 & $2,771.33$ & $5,145.28$ \\
\hline 2020 & \begin{tabular}{|l|}
$2,097.77$ \\
\end{tabular} & $1,637.97$ & $1,809.80$ & 693.81 & $2,696.35$ & $5,125.53$ \\
\hline 2021 & $2,228.69$ & $1,598.02$ & $1,688.13$ & 593.11 & $2,616.63$ & $5,104.55$ \\
\hline 2022 & $2,388.16$ & $1,551.45$ & $1,558.88$ & 488.14 & $2,531.94$ & 5.082 .27 \\
\hline 2023 & $2,510.51$ & $1,504.12$ & $1,421.63$ & 372.58 & 2.442 .03 & 5.058 .00 \\
\hline 2024 & $2,682.07$ & $1,453.91$ & $1,236.02$ & 252.08 & $2,346.63$ & $5,033.50$ \\
\hline 2025 & $2,821.21$ & $1,400.67$ & $\begin{array}{l}1,121.62 \\
\end{array}$ & 124.28 & $2,245.47$ & $5,008.88$ \\
\hline 2026 & $2,988.31$ & $1,344.25$ & 957.99 & 0.00 & $2,138.28$ & 4.978 .67 \\
\hline 2027 & $3,163.76$ & $1,284.48$ & 784.68 & 0.00 & $2,024.71$ & 4.948 .78 \\
\hline 2028 & 3.347 .98 & 1.221 .21 & 601.17| & 0.00 & $1,904.49$ & 4.917 .15 \\
\hline & 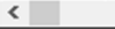 & & & & & \\
\hline
\end{tabular}

(b) Proyeksi Dinamika Perubahan Penggunaan Lahan berdasarkan skenario 1

Proyeksi Dinamika Perubahan Penggunaan Lahan berdasarkan skenario 1

Gambar 7. Hasil Simulasi Dinamika Penggunaan Lahan Skenario 1

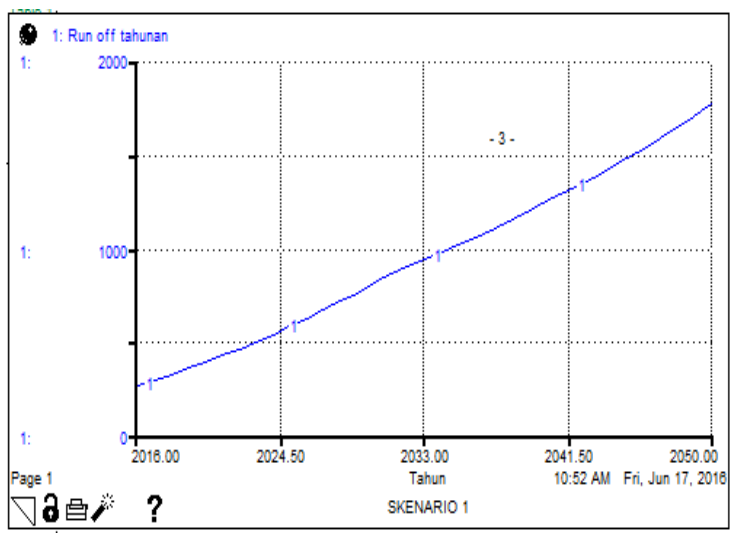

\begin{tabular}{|r|r|}
\hline Tahun & Run off tahunan \\
\hline 2016 & 259.57 \\
\hline 2017 & 288.38 \\
\hline 2018 & 318.68 \\
\hline 2019 & 350.45 \\
\hline 2020 & 383.81 \\
\hline 2021 & 418.81 \\
\hline 2022 & 455.52 \\
\hline 2023 & 494.00 \\
\hline 2024 & 534.32 \\
\hline 2025 & 576.55 \\
\hline 2026 & 620.72 \\
\hline 2027 & 684.79 \\
\hline 2028 & 710.90 \\
\hline &
\end{tabular}

Gambar 8. Hasil Simulasi Dinamika aliaran permukaan Skenario 1

B. Skenario Kebijakan II : Intervensi terhadap angka kelahiran dan laju emigrasi penduduk ke daerah puncak Bogor (Moderate).

Skenario Kebijakan II : Intervensi terhadap angka kelahiran dan laju emigrasi penduduk ke daerah puncak Bogor (Moderate).
Skenario II merupakan skenario moderate, dimana dilakukan intervensi terhadap angka kelahiran dan tingkat emigrasi. Hal ini dilakukan untuk menekan jumlah penduduk yang bermukim di kawasan puncak yang memicu penambahan luasan lahan terbangun. Hasil simulasi terhadap perilaku sistem yang menggambarkan perilaku dari dinamika populasi, dinamika perubahan penggunaan lahan dan dinamika aliran permukaan, berturut - turut disajikan pada Gambar 9, 10 dan 11.

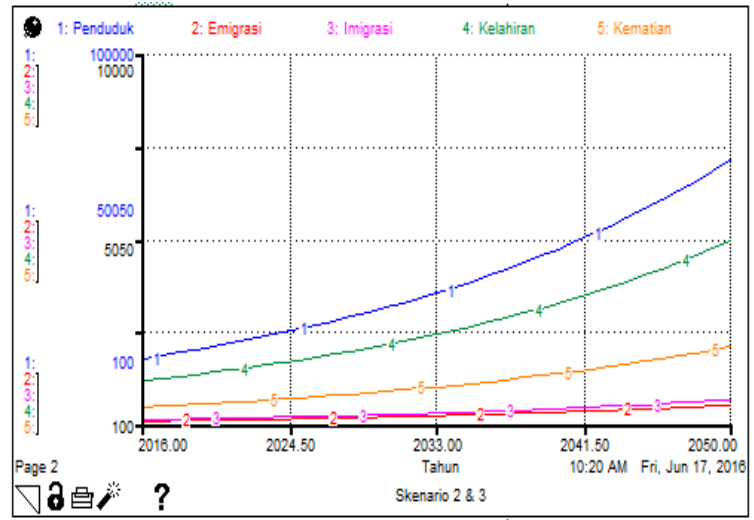

(a) Grafik Perilaku Dinamika populasi berdasarkan skenario 2

\begin{tabular}{|c|c|c|c|c|c|c|c|}
\hline \multicolumn{3}{|c|}{ 10:20 AM $8 / 17 / 2016$} & \multicolumn{3}{|c|}{ Table 3: p2 (Skenario 2 \& 3) } & \multirow[t]{2}{*}{$?$} & \multirow[t]{2}{*}{ 䈃昌 } \\
\hline Tahun & Penduduk & Kelahiran & Kematian & Imigrasi & Emigrasi & & \\
\hline 2016 & $17,000.00$ & $1,232.00$ & 528.00 & 178.00 & 140.80 & & \\
\hline 2017 & $18,339.20$ & $1,283.74$ & 550.18 & 183.39 & 148.71 & & \\
\hline 2018 & $19,109.45$ & $1,337.68$ & 573.28 & 191.09 & 152.88 & & \\
\hline 2019 & $19,912.04$ & $1,393.84$ & 597.38 & 199.12 & 159.30 & & \\
\hline 2020 & $20,748.35$ & $1,452.38$ & 622.45 & 207.48 & 165.99 & & \\
\hline 2021 & $21,619.78$ & $1,513.38$ & 648.59 & 216.20 & 172.96 & & \\
\hline 2022 & $22,527.81$ & $1,576.95$ & 675.83 & 225.28 & 180.22 & & \\
\hline 2023 & $23,473.98$ & $1,843.18$ & 704.22 & \begin{tabular}{|l|l|}
234.74 \\
\end{tabular} & 187.79 & & \\
\hline 2024 & $24,459.89$ & $1,712,19$ & 733.80 & 244.60 & 195.88 & & \\
\hline 2025 & $25,487.20$ & $1,784.10$ & 764.62 & 254.87 & 203.90 & & \\
\hline 2028 & $28,557.68$ & $1,859.04$ & 796.73 & 285.58 & 212.48 & & \\
\hline 2027 & $27,673.08$ & \begin{tabular}{|l|l|}
$1,937,12$ \\
\end{tabular} & 830.19 & 276.73 & 221.38 & & \\
\hline 2028 & $28,835.35$ & $2,018.47$ & 885.06 & 288.35 & 230.88 & & \\
\hline$\nabla$ & $<$ & & & & & & $>$ \\
\hline
\end{tabular}

(b) Proyeksi Dinamika Populasi berdasarkan skenario 2

Gambar 9. Hasil Simulasi Dinamika Populasi pada Skenario 2

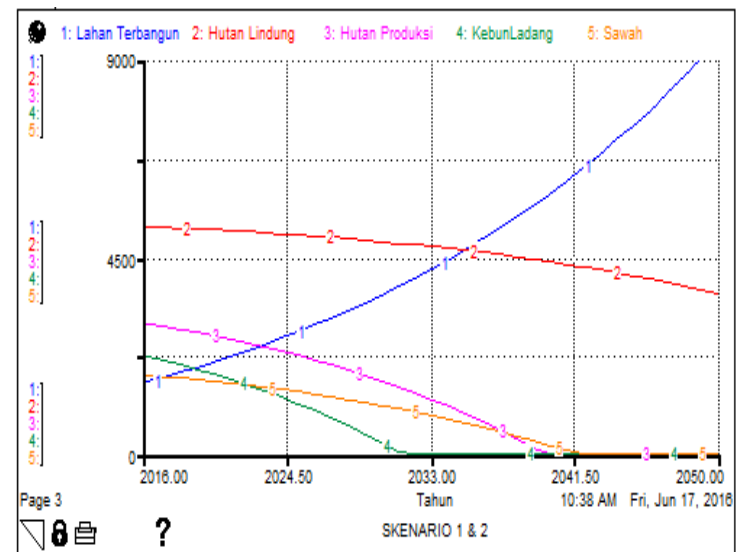

(a) Grafik Perilaku Dinamika Perubahan Penggunaan Lahan berdasarkan skenario 2 


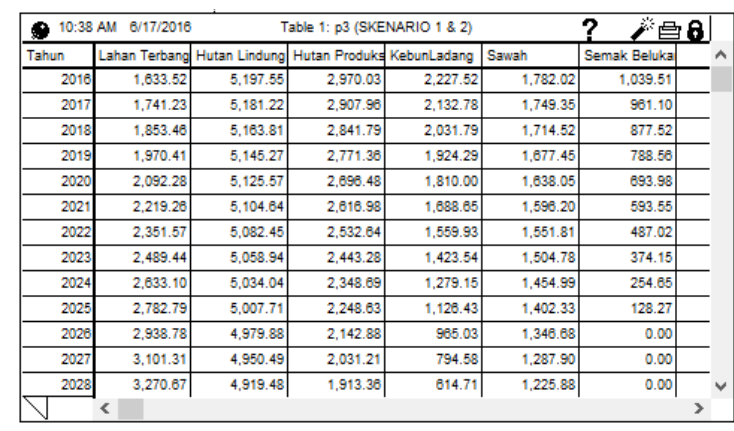

(b) Proyeksi Dinamika Perubahan Penggunaan Lahan berdasarkan skenario 2

Gambar 10. Hasil Simulasi Dinamika Penggunaan Lahan Skenario 2

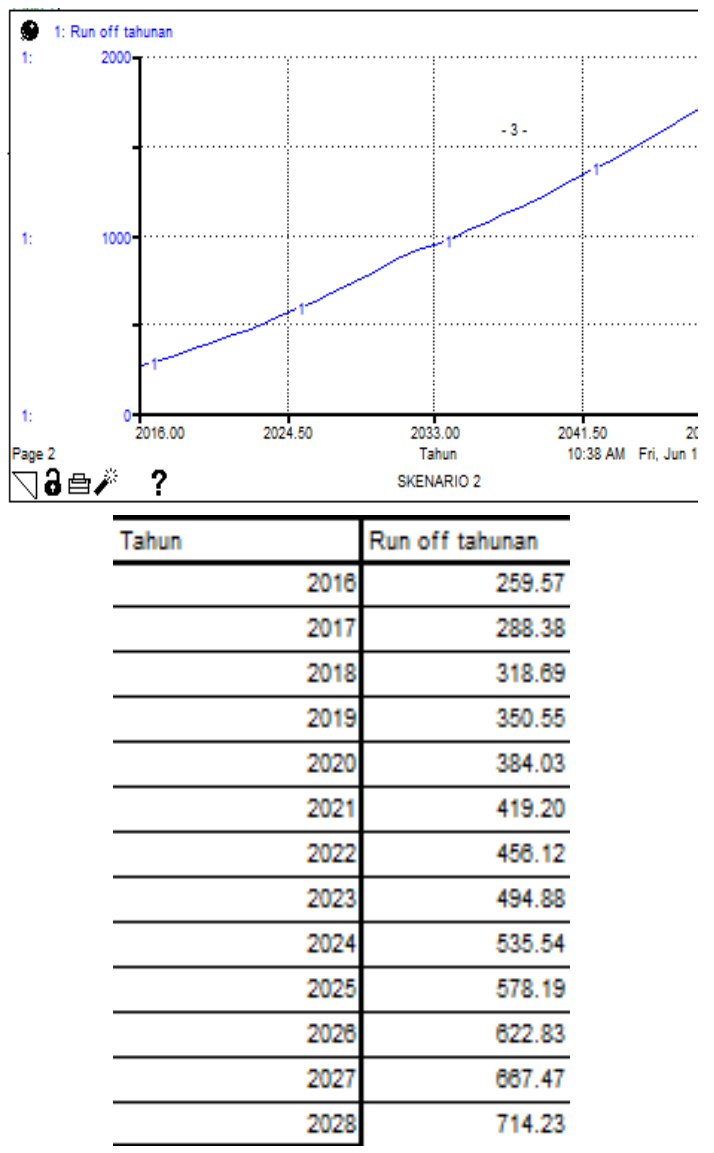

Gambar 11. Hasil Simulasi Dinamika aliaran permukaan Skenario 2

C. Skenario Kebijakan III : Intervensi terhadap angka kelahiran dan laju emigrasi penduduk ke daerah puncak Bogor dan memperketat aturan Pengendalian Tata Ruang (Optimis).

Skenario Kebijakan III : Intervensi terhadap angka kelahiran dan laju emigrasi penduduk ke daerah puncak Bogor dan memperketat aturan Pengendalian Tata Ruang (Optimis).
Skenario III merupakan skenario Optimis, dimana dilakukan intervensi terhadap angka kelahiran dan tingkat emigrasi dan juga memperketa auturan pengendalian tata ruang. Terkait pemenuhan kebutuhan lahan untuk area terbangun, pada skenario ini Hutan Lindung di larang dengan tegas untuk dilakukan konversi dan perambahan, sedangkan hutan produksi mulai tahun 2019 tidak diizinkan untuk dilakukan konversi menjadi area terbangun. Hal ini dilakukan untuk menekan jumlah penduduk yang bermukim di kawasan puncak yang memicu penambahan luasan lahan terbangun. Hasil simulasi terhadap perilaku sistem yang menggambarkan perilaku dari dinamika populasi, dinamika perubahan penggunaan lahan dan dinamika aliran permukaan, berturut - turut disajikan pada Gambar 12, 13 dan 14.

Grafik Perilaku Dinamika populasi berdasarkan skenario III

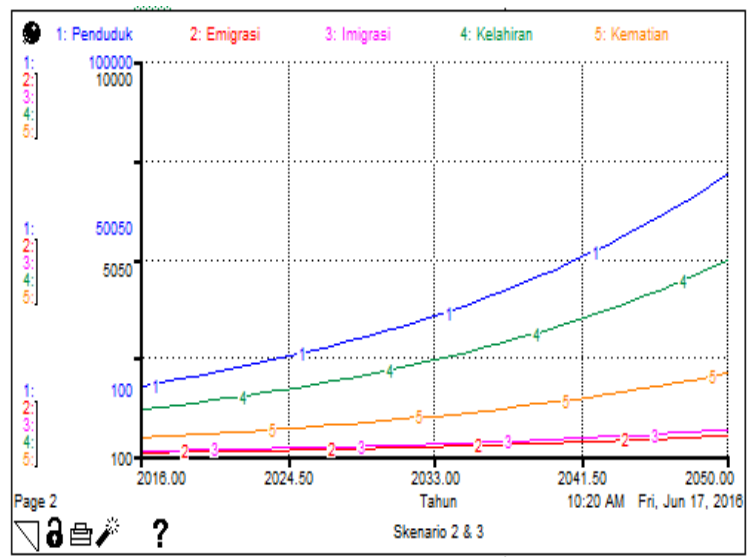

(a) Grafik Perilaku Dinamika populasi berdasarkan Skenario 3

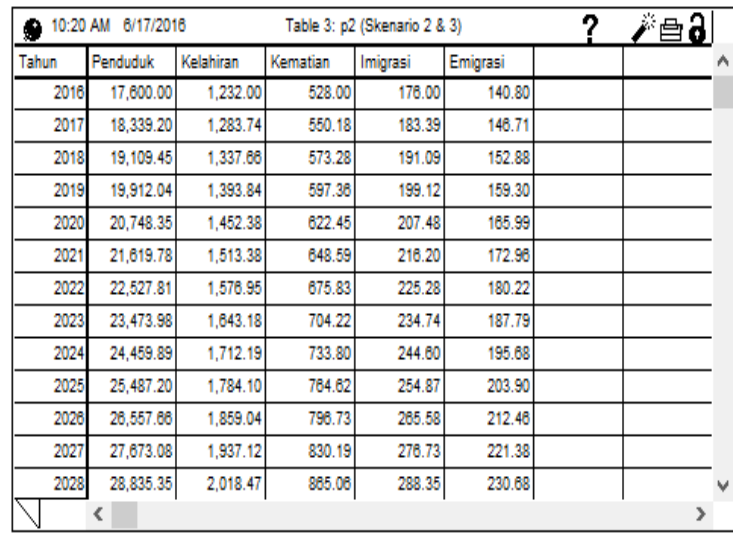

(b) Proyeksi Dinamika Populasi berdasarkan Skenario 3

Gambar 9. Hasil Simulasi Dinamika Populasi pada Skenario 3 


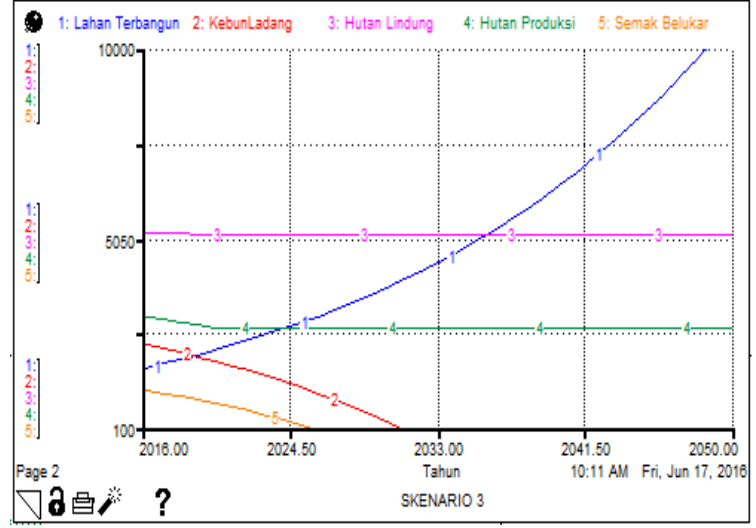

(a) Grafik Perilaku Dinamika Perubahan Penggunaan Lahan berdasarkan Skenario 3

\begin{tabular}{|c|c|c|c|c|c|c|}
\hline \multicolumn{3}{|c|}{ 10:11 AM B/17/2016 } & \multicolumn{3}{|c|}{ Table 1: p2 (Skenario 3) } & \multirow{2}{*}{ 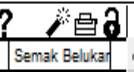 } \\
\hline Tahun & Lahan Terbang & Hutan Lindung & Hutan Produks & KebunLadang & Sawah & \\
\hline 2016 & $1,633.52$ & $5,197.55$ & $2,970.03$ & $2,227.52$ & $1,782.02$ & $1,039.51$ \\
\hline 2017 & $1,741.23$ & $5,181.22$ & $2,907.96$ & $2,132.78$ & 1,749.35 & 961.10 \\
\hline 2018 & 1,854.33 & $5,183.81$ & $2,841.79$ & $2,031.79$ & 1,714.52 & 877.52 \\
\hline 2019 & $1,973.08$ & $5,145.28$ & $2,771.33$ & $1,924.24$ & $1,877.44$ & 788.52 \\
\hline 2020 & $2,097.77$ & $5,145.28$ & $2,896.35$ & 1,809.80 & $1,637.97$ & 693.81 \\
\hline 2021 & $2,228.69$ & $5,145.28$ & $2,896.35$ & $1,688.13$ & $1,596.02$ & 593.11 \\
\hline 2022 & $2,386.16$ & $5,145.28$ & $2,696.35$ & $1,558.88$ & $1,551.45$ & 488.14 \\
\hline 2023 & $2,510.51$ & $5,145.28$ & $2,696.35$ & $1,421.63$ & $1,504.12$ & 372.58 \\
\hline 2024 & $2,662.07$ & $5,145.28$ & $2,696.35$ & $1,278.02$ & $1,453.91$ & 252.06 \\
\hline 2025 & $2,821.21$ & $5,145.28$ & $2,696.35$ & $1,121.62$ & $1,400.67$ & 124.28 \\
\hline 2028 & $2,988.31$ & $5,145.26$ & $2,696.35$ & 957.99 & $1,344.25$ & 0.00 \\
\hline 2027 & $3,183.76$ & $5,145.28$ & $2,696.36$ & 784.68 & $1,284.48$ & 0.00 \\
\hline 2028 & $3,347.98$ & $5,145.26$ & $2,698.35$ & 601.17 & $1,221.21$ & $0.00 \mid \checkmark$ \\
\hline V & $<$ & & & & & $>$ \\
\hline
\end{tabular}

(b) Proyeksi Dinamika Perubahan Penggunaan Lahan berdasarkan Skenario 3

Gambar 12. Hasil Simulasi Dinamika Penggunaan Lahan Skenario II

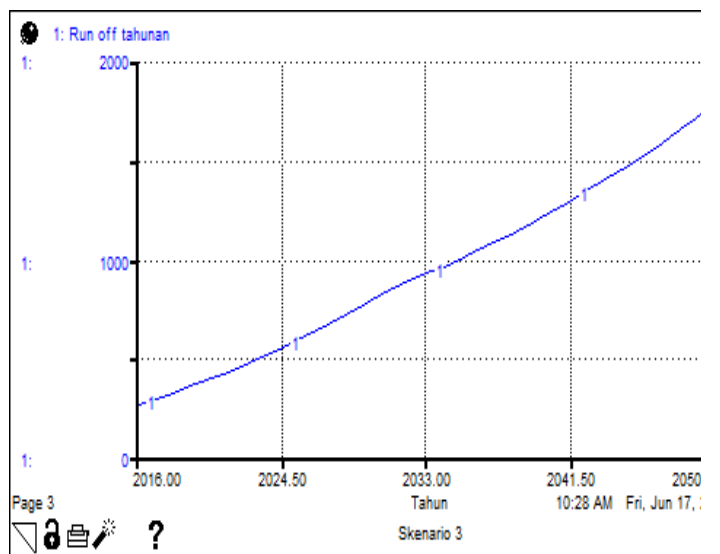

\begin{tabular}{r|r|}
\hline \multicolumn{1}{|l|}{ Tahun } & Run off tahunan \\
\hline 2016 & 259.57 \\
\hline 2017 & 288.38 \\
\hline 2018 & 318.69 \\
\hline 2019 & 350.55 \\
\hline 2020 & 383.99 \\
\hline 2021 & 418.21 \\
\hline 2022 & 454.12 \\
\hline 2023 & 491.81 \\
\hline 2024 & 531.34 \\
\hline 2025 & 572.80 \\
\hline 2026 & 616.17 \\
\hline 2027 & 659.47 \\
\hline 2028 & 704.83 \\
\hline
\end{tabular}

Gambar 13. Hasil Simulasi Dinamika aliaran permukaan Skenario 3

\section{Perbandingan Pengendalian Aliran Permukaan berdasarkan Hasil simulasi pada skenario I, II dan III.}

Perbandingan Pengendalian Aliran Permukaan berdasarkan Hasil simulasi pada skenario I, II dan III.

Peningkatan akan laju aliran permukaan dipicu oleh peningkatan jumlah penduduk yang berdampak langsung pada peningkatan kebutuhan lahan untuk area terbangun. Hal ini berdampak signifikan terhadap peningkatan laju aliran permukaan setiap tahunnya. Upaya pengendalian akan peningkatan aliran permukaan dapat dilakukan dengan menerapkan beberapa skenario kebijakan. Tabel 2, menyajikan perbandingan hasil simulasi aliran permukaan berdasarkan skenario 1, 2 dan 3 .

Tabel 2. Perbandingan Hasil Simulasi aliran permukaan berdasarkan skenario 1, 2 dan 3 .

\begin{tabular}{cccc}
\hline \multirow{2}{*}{ Tahun } & \multicolumn{3}{c}{ Aliran Permukaan (mm/Tahun) } \\
\cline { 2 - 4 } & Skenario I & Skenario II & Skenario III \\
\hline 2016 & 259.57 & 259.57 & 259.57 \\
\hline 2017 & 288.38 & 288.38 & 288.38 \\
\hline 2018 & 318.69 & 318.66 & 318.69 \\
\hline 2019 & 350.55 & 350.45 & 350.55 \\
\hline 2020 & 384.03 & 383.99 & 383.81 \\
\hline 2021 & 419.20 & 418.81 & 418.21 \\
\hline 2022 & 456.12 & 455.52 & 454.12 \\
\hline 2023 & 494.88 & 494.00 & 491.81 \\
\hline 2024 & 535.54 & 534.32 & 531.34 \\
\hline 2025 & 578.19 & 576.55 & 572.80 \\
\hline 2026 & 622.83 & 620.72 & 616.17 \\
\hline
\end{tabular}




\begin{tabular}{rrrr}
\hline 2027 & 667.47 & 664.79 & 659.47 \\
\hline 2028 & 714.23 & 710.90 & 704.83 \\
\hline 2029 & 763.21 & 759.12 & 752.32 \\
\hline 2030 & 814.50 & 809.54 & 802.04 \\
\hline 2031 & 868.19 & 862.24 & 854.09 \\
\hline 2032 & 905.56 & 899.35 & 889.73 \\
\hline 2033 & 943.19 & 935.92 & 925.53 \\
\hline 2034 & 982.43 & 974.01 & 962.85 \\
\hline 2035 & 1023.37 & 1013.68 & 1001.77 \\
\hline
\end{tabular}

Tabel 2, menunjukan trend peningkatan laju aliran permukaan setiap tahunnya sebagai dampak dari peningkatan penduduk dan peningkatan area terbangun. Namun demikian, upaya pengendalian terhadap peningkatan aliran permukaan dapat dilakukan dengan beberapa skenario kebijakan. Intervensi terhadap model dilakukan pada skenario 2 dan 3. Intervensi kebijakan yang dilakukan pada skenario 2 adalah dengan melakukan intervensi terhdapa penekanan angka kelahiran dan emigrasi. Intervensi yang dilakukan pada skenario 3 adalah sama dengan skenario dua dengan tambahan pengendalian tata ruang lebih diperketat dimana ada pembatasan pada tahun 2019 untuk area hutan produksi tidak diizinkan untuk di alih fungsikan menjadi lahan terbangun. Hal tersebut dilakukan untuk memperkuat fungsi DAS Ciliwung Hulu debagai daerah lindung dan resapan. Berdasarkan intervensi yang dilakukan terhadap sistem, sesuai dengan skenario I dan II, secara signifikan mampu menurunkan laju aliran permukaan dibandingkan dengan kondisi eksisting tanpa dilakukan intervensi kebijakan.

\section{KESIMPULAN DAN REKOMENDASI}

Hasil pemodelan menunjukkan bahwa Peningkatan akan laju aliran permukaan dipicu oleh peningkatan jumlah penduduk yang berdampak langsung pada peningkatan kebutuhan lahan untuk area terbangun. Hal ini berdampak signifikan terhadap peningkatan laju aliran permukaan setiap tahunnya. Upaya pengendalian akan peningkatan aliran permukaan dapat dilakukan dengan menerapkan beberapa skenario kebijakan.

Berdasarkan hasil simulasi, skenario III memberikan hasil yang terbaik dalam upaya pengendalian aliran permukaan di DAS Ciliwung Hulu. Skenario III didasarkan pada kebijakan dengan intervensi penekanan angka kelahiran dan emigrasi dan juga pengendalian terhadap tata ruang memberikan hasil yang cukup signifikan untuk menurunkan laju aliran permukaan dibandingkan dengan kondisi eksisting tanpa dilakukan intervensi kebijakan.

\section{DAFTAR PUSTAKA}

Grant, W. E, E. K. Pedersen and S. L. Marin. 1997. Ecology and Natural Resources Management : System Analysis and Simulation. John Wiley \& Sos, Inc. Toronto Canada

Hadi S. 2012. Arahan pemanfaatan Ruang Kawasan Puncak dalam perspektif kajian akademis (Isu dan permasalahan perubahan pola ruang kawasan strategis puncak). Pusat Pengkajian Perencanaan dan Pengembangan wilayah, LPPM-IPB.

Hartrisari. 2002. Panduan Lokakarya Analisis Prospektif. Bogor: Fakultas Teknologi Pertanian. Institut Pertanian Bogor.

Jorgensen. S. E., 1986. Fundamentals of Ecological Modelling. Elsevier. New York.

Kodoatie, J. R. \& R. Sjarief. 2005. Pengelolaan Sumber Daya Air Terpadu. Penerbit Andi. Yogyakarta.

Kuncahyo, Budi. 2015. Pemodelan Sistem dengan Analisis Regresi. Divisi Perencanaan Hutan. Departemen Manajemen Hutan. Fakultas Kehutanan. Institut Pertanian Bogor.

Lee, R. Hidrologi Hutan. S. Subagio, penerjema h; Yogyakarta; Gadjah Mada University Press.

Purnomo H, 2005. Teori Sistem Kompleks, Pemodelan dan Simulasi untuk Pengelolaan Sumberdaya Alam dan Lingkungan. Fakultas Kehutanan Institut Pertanian, Bogor.

Purnomo H. 2012. Pemodelan dan simulasi untuk pengelolaan adaptif sumberdaya alam dan lingkungan. IPB Press. Bogor.

Seyhan, E. 1990. Dasar-dasar Hidrologi. S. Subagyo, penerjemah; Yogyakarta; Gadjah Mada University Press.

Skartveit HL, Goodnow K, Viste M. 2003. Visualized System Dynamics Models as Information and Planning Tools. Informing Science InSITE. University of Bergen Norway.

Sunaryo, Suprayogo, D., dan Lusiana B. 2006. Stella dan Model Wanulcas. 
Voinov A, 2008. Systems Science and Modeling

for Ecological Economics.Elsevier, http://elsevierdirect.com

\section{Lampiran 1. Equation pada Sub Model Dinamika Penduduk}

\section{Sub Model Penduduk}

Penduduk $(\mathrm{t})=$ Penduduk $(\mathrm{t}-\mathrm{dt})+($ Kelahiran + Imigrasi - Kematian - Emigrasi $){ }^{*} \mathrm{dt}$

INIT Penduduk $=17600$

INFLOWS:

$\Longrightarrow$ Kelahiran $=$ Penduduk ${ }^{*}$ Angka_kelahiran

$\Rightarrow$ Imigrasi $=$ Penduduk*Tingkat_Imigrasi

OUTFLOWS:

$\Rightarrow$ Kematian $=$ Penduduk ${ }^{*}$ Angka_Kematian

$\Longrightarrow$ Emigrasi $=$ Penduduk ${ }^{*}$ Tingkat_Emigrasi

Angka_kelahiran $=0.07$

Angka_Kematian $=0.03$

Tingkat_Emigrasi $=0.01$

Tingkat_Imigrasi $=0.02$

\section{Lampiran 2. Equation pada Sub Model Dinamika Perubahan Penggunaan Lahan}

\section{Sub Model Landuse}

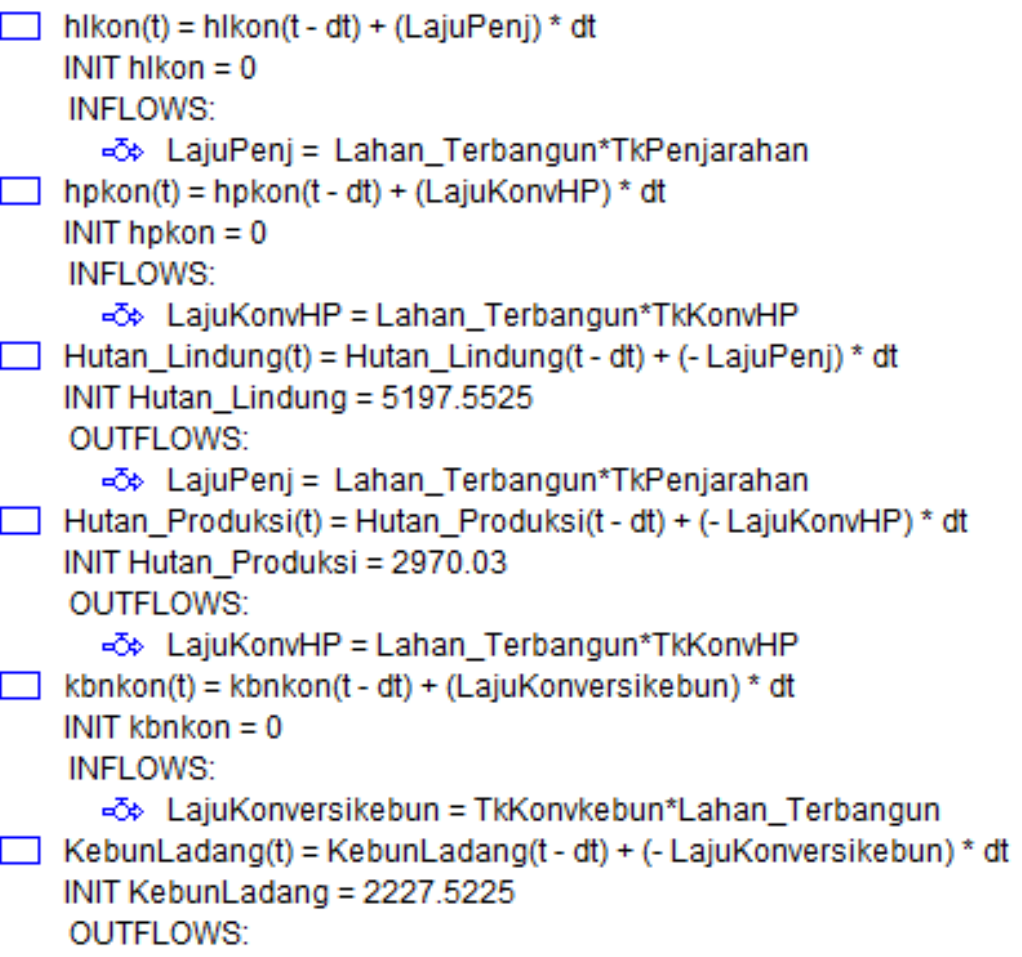


$\Longrightarrow$ LajuKonversikebun = TkKonvkebun*Lahan_Terbangun

Lahan_Terbangun $(\mathrm{t})=$ Lahan_Terbangun $(\mathrm{t}-\mathrm{dt})+($ LajuKebutuhan_lahan_terbangun $){ }^{*} \mathrm{dt}$ INIT Lahan_Terbangun $=1633.517$

INFLOWS:

$\triangle \varnothing$ LajuKebutuhan_lahan_terbangun = Kebutuhan_Lahan_Terbangun

Sawah $(\mathrm{t})=$ Sawah $(\mathrm{t}-\mathrm{dt})+(-$ LajuKonversisawah $){ }^{*} \mathrm{dt}$

INIT Sawah $=1782.018$

OUTFLOWS:

$\triangle \varnothing$ LajuKonversisawah $=$ Tkkonvsawah*Lahan_Terbangun

$\square$ Semak_Belukar $(\mathrm{t})=$ Semak_Belukar $(\mathrm{t}-\mathrm{dt})+\left(-\right.$ LajuKonvrsemak ${ }^{*} \mathrm{dt}$ INIT Semak_Belukar $=1039.5105$

OUTFLOWS:

$\triangle$ ¿ $\Rightarrow$ LajuKonvrsemak $=$ TkKonvsemakbelukar*Lahan_Terbangun

$\square$ smkkon $(\mathrm{t})=$ smkkon $(\mathrm{t}-\mathrm{dt})+(\text { LajuKonvrsemak })^{*} \mathrm{dt}$

INIT smkkon $=0$

INFLOWS:

$\triangle \Phi$ LajuKonvrsemak $=$ TkKonvsemakbelukar*Lahan_Terbangun

$\square$ swkon $(\mathrm{t})=\operatorname{swkon}(\mathrm{t}-\mathrm{dt})+($ LajuKonversisawah $){ }^{*} \mathrm{dt}$

INIT swkon $=0$

INFLOWS:

$\triangle \varnothing$ LajuKonversisawah = Tkkonvsawah*Lahan_Terbangun

$\bigcirc$ Kebutuhan_Lahan_Terbangun $=$ Penduduk ${ }^{*} 0.00612$

TkKonvHP $=0.038$

$\bigcirc$ TkKonvkebun $=0.058$

$\bigcirc$ Tkkonvsawah $=0.02$

TkKonvsemakbelukar $=0.048$

TkPenjarahan $=0.01$

\section{Lampiran 3. Equation pada Sub Model Dinamika Aliran Permukaan}

\section{Sub Model Aliran Permukaan}

$\bigcirc$ RO_HL $=(\text { hlkon } / 1000)^{\star} 22.7^{\star} 0.01$

RO_HP $=(\text { hpkon } / 1000)^{*} 0.05^{\star} 22.7$

RO_KL $=(\text { kbnkon } / 1000)^{\star} 22.7{ }^{*} 0.4$

$\bigcirc$ RO_LT $=(\text { Lahan_Terbangun } / 1000)^{\star} 22.7^{\star} 0.7$

RO_S $=(\text { swkon } / 1000)^{*} 22.7^{\star} 0.15$

$\bigcirc$ RO_SB $=(\text { smkkon } / 1000)^{\star} 22.7^{\star} 0.07$

O Run_off_tahunan $=\mathrm{RO} \_H L+R O \_H P+R O \_K L+R O \_L T+R O \_S+R O \_S B$ 